JURNAL RESPIRASI

JR

Vol. 5 No. 3 September 2019

\title{
Profil Pasien Kanker Paru Primer yang Dirawat Inap dan Rawat Jalan di Rumah Sakit Umum Daerah Dr Soetomo Surabaya
}

\author{
Muhammad Rudy Chairudin ${ }^{1 *}$, Isnin Anang Marhana ${ }^{2}$, Dyah Erawati ${ }^{3}$ \\ ${ }^{1}$ Fakultas Kedokteran Universitas Airlangga Surabaya, Indonesia \\ ${ }^{2}$ Departemen Pulmonologi dan Ilmu Kedokteran Respirasi Fakultas Kedokteran Universitas Airlangga, Surabaya, \\ Indonesia \\ ${ }^{3}$ Departemen Radiologi Fakultas Kedokteran Universitas Airlangga, Surabaya, Indonesia
}

\begin{abstract}
Background: Lung cancer is still one of the biggest contributors to cancer deaths. GLOBOCAN in 2012 reported that lung cancer causes $30 \%$ of cancer deaths in men and $11.1 \%$ in women. Objective: The purpose of this study was to determine the profile of lung cancer in the General Academic Hospital Dr. Soetomo.Method: This research uses a descriptive observasional type by taking one time through medical record data from 186 primary lung cancer patients in Dr. Soetomo Hospital during January to December 2017. Results: Men (70.4\%) more than women (29.6\%). The most age group is 51-60 years (35.5\%). Men and women suffer the most from adenocarcinoma (78.6\% and 87.3\%). Most jobs are private employees (38.2\%). Most education is high school (70.4\%). The most of patients live in East Java (97.3\%) and the most specific are in Surabaya (39.2\%). Most Histopathology is non-small cell lung cancer $(95.9 \%)$ with adenocarcinoma is the most common type (81\%). Lung cancer with small cell and non small cell type are mostly found in stage IV (82.3\%) and extensive stage (3.8\%). Local metastases are mostly found in the contralateral lung (58.1\%), and most distant metastases in the brain organ (66.7\%). The most common complication is pleural effusion (42.5\%). Shortness of breath is the most common symptom (59.1\%). The most widely used chemotherapy drug is pemetrexedcisplatin (17.1\%). Conclusion: Primary lung cancer patients at Dr. Soetomo Regional Academic Hospital majority of men aged 51-60 years. Most local metastases are in the contralateral lung and distant metastases in the brain. Most complications are pleural effusion.
\end{abstract}

Keywords: Primary lung cancer, descriptive. age, sex, metastases

Correspondence Author: Muhammad Rudy Chairudin, Fakultas Kedokteran Universitas Airlangga, Surabaya, Indonesia. Jalan Mayjen Prof. Dr. Moestopo 47 Surabaya. e-mail: mrudy_c@yahoo.com

\section{PENDAHULUAN}

Kanker adalah perkembangan sel-sel ganas yang tidak mampu dikendalikan oleh tubuh dan dalam proses ganasnya dapat menyebar ke jaringan sekitar atau lebih jauh. ${ }^{1}$ Pada tahun 2018, kematian yang disebabkan oleh kanker mencapai 9,6 juta jiwa. ${ }^{2}$ Salah satu kanker dengan angka mortalitas yang tinggi tersebut adalah kanker paru dengan rata-rata $13 \%$ dari semua kasus kanker yang baru terdiagnosa. ${ }^{3}$

Pada tahun 2014, kanker paru di Indonesia pada laki-laki menempati posisi pertama sebagai penyebab kematian akibat kanker $(21,8 \%)$, kemudian liver $(12,3 \%)$, dan kolorektal $(10,2 \%)$ dari 103.100 kematian. Sedangkan pada perempuan Indonesia, kanker paru di urutan ketiga sebagai penyebab kematian akibat kanker $(9,1 \%)$ setelah kanker payudara $(21,4 \%)$, dan kanker serviks $(10,3 \%)$ dari 92.200 kematian. $^{4}$

Angka kelangsungan hidup pada pasien kanker paru masih termasuk rendah. Di Amerika, angka kelangsungan hidup pasien kanker paru dalam 5 tahun setelah terdiagnosa termasuk salah satu yang terendah $(18,6 \%)$ dibandingkan kanker lainnya seperti kolorektal $(64,5 \%)$, payudara $(89,6 \%)$, dan prostat $(98,2 \%) .^{5}$

Dengan angka mortalitas yang tinggi dan angka kelangsungan hidup yang rendah, pentingnya dilakukan deteksi dini dan tindakan pencegahan baik primer dan sekunder terhadap golongan yang berisiko kanker paru primer. Profil kanker paru primer sebagai data epidemiologi sangat dibutuhkan dalam mengenali karakteristik dari kanker paru tersebut. Oleh karena itu, kami tertarik melakukan penelitian ini menggunakan data RSUD Dr. Soetomo yang merupakan pusat rujukan di Indonesia bagian timur agar data epidemiologi kanker paru di Indonesia lebih banyak dan variasinya dapat diamati sehingga sasaran program deteksi dini, dan pencegahan terhadap golongan yg berisiko tinggi kanker paru oleh pemerintah dan instansi terkait dapat lebih efektif. 


\section{METODE}

Penelitian ini berjenis deskriptif observasional dengan desain cross sectional melalui pengambilan data sekunder berupa rekam medis sekali waktu. Penelitian dilakukan mulai dari bulan maret 2018 hingga Mei 2019. Sampel penelitian ini adalah 186 pasien kanker paru yang melalui proses anamnesis, pemeriksaan fisik, dan pemeriksaan penunjang tergolong sebagai kanker paru primer. Kemudian data disaring menurut kriteria inklusi dan ekslusi. Sampel diambil dengan teknik total sampling. Adapun kriteria inklusi Pasien kanker paru primer berdasarkan data rekam medis RSUD Dr. Soetomo tahun 2017 dan memiliki data rekam medis yang lengkap (usia, jenis kelamin, pendidikan, pekerjaan, domisili, gejala klinis, hasil patologi anatomi, stadium kanker, lokasi metastasis kanker, komplikasi, terapi yang dilakukan, dan regimen kemoterapi). Data terekslusi apabila dalam proses pemriksaan pasien terdiagnosis kanker paru sekunder, mempunyai riwayat kanker bukan paru sebelumnya yang telah sembuh atau masih dalam terapi dan data di dalam rekam medis tidak lengkap sesuai variabel penelitian.

\section{HASIL}

Pada gambar 1 didapatkan bahwa pasien kanker paru primer paling sering ditemukan pada rentang usia 51-60 tahun (35,5\%) dan 61-70 tahun dengan 53 kasus (28,5\%). Adapun rata-rata usia pasien pada penelitian ini yaitu 55,5 tahun. Kasus termuda ditemukan pada usia 14 tahun dan paling tua pada usia 84 tahun.
Tabel 1. Distribusi Silang Antara Jenis Kelamin dengan Histopatologi Anatomi Pasien Kanker Paru Primer Rumah Sakit Umum Daerah Dr. Soetomo yang Dirawat Inap dan Rawat Jalan Tahun 2017

\begin{tabular}{|c|c|c|c|c|c|c|c|}
\hline \multirow{3}{*}{$\begin{array}{c}\text { Jenis } \\
\text { Kelamin }\end{array}$} & \multicolumn{7}{|c|}{ Jenis Histopatologi Anatomi } \\
\hline & \multicolumn{2}{|c|}{$\begin{array}{c}\text { Adeno- } \\
\text { karsinoma }\end{array}$} & \multicolumn{2}{|c|}{$\begin{array}{c}\text { Karsinoma } \\
\text { Sel } \\
\text { Skuamosa }\end{array}$} & \multicolumn{2}{|c|}{$\begin{array}{c}\text { Kanker } \\
\text { Paru Sel } \\
\text { Kecil }\end{array}$} & Total \\
\hline & $\mathrm{n}$ & $\%$ & $\mathrm{n}$ & $\%$ & $\mathrm{n}$ & $\%$ & $\%$ \\
\hline Laki-laki & 103 & 78,6 & 21 & 16,0 & 7 & 5,4 & $131 \quad 100$ \\
\hline Perempuan & 48 & 87,3 & 6 & 10,9 & 1 & 1,8 & $55 \quad 100$ \\
\hline
\end{tabular}

Dari gambar 2 didapatkan distribusi pasien kanker paru primer paling banyak ditemukan pada tingkatan pendidikan SLTA dengan 131 kasus $(70,4 \%)$, sedangkan riwayat pendidikan yang jarang ditemui adalah sarjana dengan 5 kasus $(2,7 \%)$ dan diploma dengan 3 kasus $(1,6 \%)$.

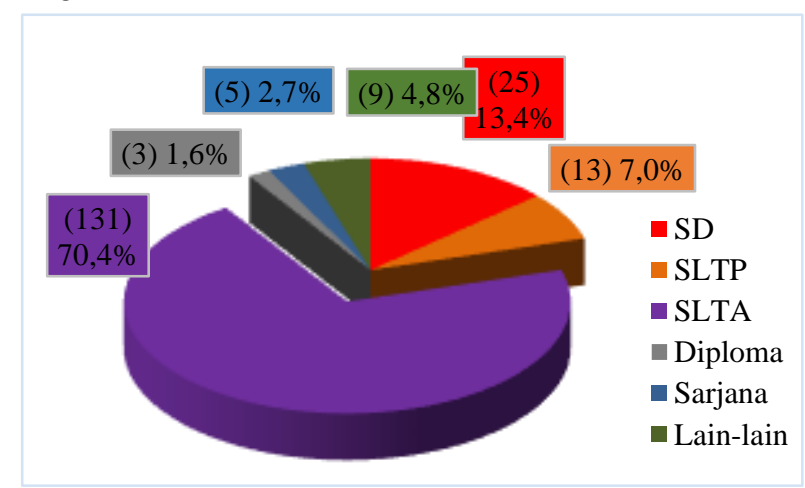

Gambar 2. Distribusi Pendidikan Pasien Kanker Paru Primer Rumah Sakit Umum Daerah Dr. Soetomo yang Dirawat Inap dan Rawat Jalan Tahun 2017

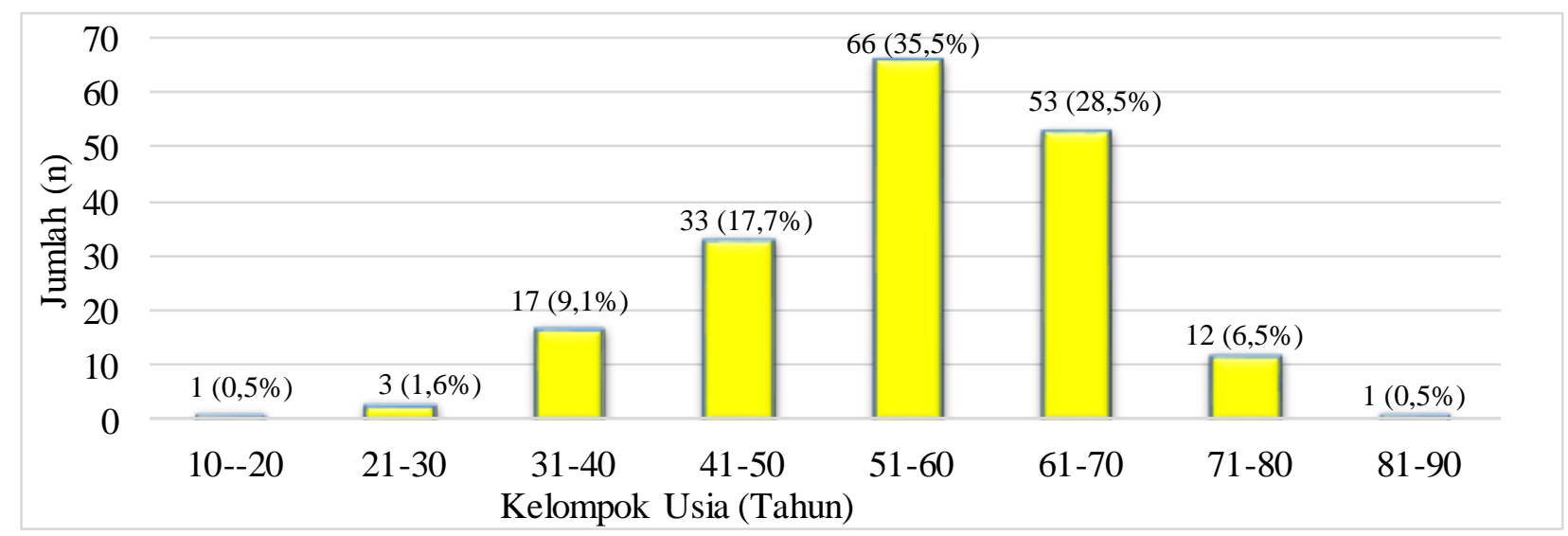

Gambar 1. Distribusi Usia Pasien Kanker Paru Primer Rumah Sakit Umum Daerah Dr. Soetomo yang Dirawat Inap dan Rawat Jalan Tahun 2017 
Tabel 3. Distribusi Pekerjaan Pasien Kanker Paru Primer Rumah Sakit Umum Daerah Dr. Soetomo yang Dirawat Inap dan Rawat Jalan Tahun 2017

\begin{tabular}{lcc}
\hline \multirow{2}{*}{ Pekerjaan Pasien } & \multicolumn{2}{c}{ Jumlah } \\
\cline { 2 - 3 } & $\mathrm{n}$ & $\%$ \\
\hline Pegawai Swasta & 71 & 38,2 \\
Pegawai Pemerintah / PNS & 36 & 19,4 \\
Ibu Rumah Tangga & 21 & 11,3 \\
Petani & 16 & 8,6 \\
Wirausaha & 14 & 7,5 \\
Pensiunan & 8 & 4,3 \\
Tentara / Polisi & 5 & 2,7 \\
Nelayan & 3 & 1,6 \\
Pelajar/Mahasiswa & 2 & 1,1 \\
Tukang batu & 2 & 1,1 \\
Supir & 2 & 1,1 \\
Pedagang & 1 & 0,5 \\
Pekerja lepas & 1 & 0,5 \\
Lain-lain & 4 & 2,2 \\
\hline Total & 186 & 100 \\
\hline
\end{tabular}

Tabel 4. Distribusi Stadium Kanker Paru Primer Pada Pasien Rawat Inap dan Rawat Jalan Rumah Sakit Umum Daerah Dr. Soetomo Tahun 2017

\begin{tabular}{lcc}
\hline \multirow{2}{*}{ Stadium Kanker Paru } & \multicolumn{2}{c}{ Jumlah } \\
\cline { 2 - 3 } Kanker Paru Bukan Sel Kecil & $\mathrm{n}$ & $\%$ \\
IA & 0 & 0 \\
IB & 0 & 0 \\
IIA & 0 & 0 \\
IIB & 4 & 2,1 \\
IIIA & 3 & 1,6 \\
IIIB & 23 & 12,4 \\
IV & 149 & 80,1 \\
Kanker Paru Sel Kecil & & \\
Limited & 0 & 0 \\
Extensive & 7 & 3,8 \\
Total & 186 & 100 \\
\hline
\end{tabular}

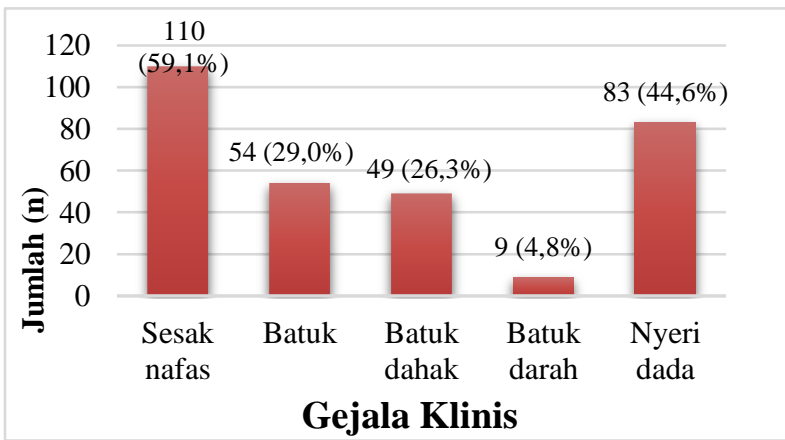

Gambar 4. Distribusi Gejala Klinis Pasien Kanker Paru Primer yang Dirawat Inap dan Rawat Jalan di Rumah Sakit Umum Daerah Dr. Soetomo Tahun 2017

Dari tabel 3 didapatkan distribusi pasien kanker paru primer memiliki latar belakang pekerjaan terbanyak sebagai pegawai swasta dengan 71 kasus $(38,2 \%)$ dan jarang ditemui pada pekerjaan pedagang dan pekerja lepas dengan 1 kasus $(0,5 \%)$.

Pada gambar 3 menunjukkan distribusi pasien kanker paru primer terbanyak di Jawa Timur adalah Surabaya dengan 73 kasus $(39,2 \%)$ diikuti Sidoarjo dengan 22 kasus $(11,8 \%)$.

Berdasarkan gambar 4, didapatkan bahwa gejala klinis pasien kanker paru terbanyak adalah sesak napas dengan 110 kasus $(59,1 \%)$ diikuti dengan nyeri dada dengan 83 kasus $(44,6 \%)$, batuk biasa dengan 54 kasus $(29,0 \%)$, batuk dahak dengan 49 kasus (26,3\%), dan batuk darah dengan 9 kasus $(4,8 \%)$.

\section{Penyebaran Daerah Pasien Kanker Paru Primer RSUD Dr.Soetomo di Jawa Timur Tahun 2017}

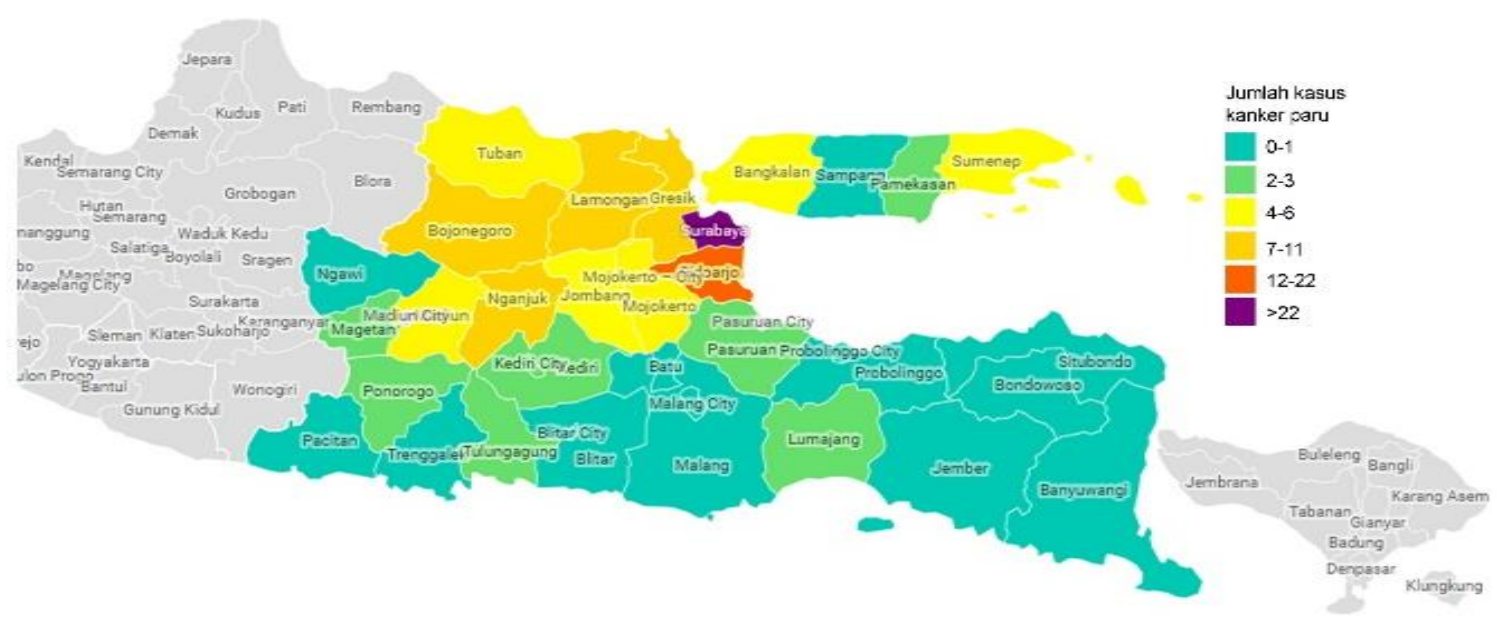

Gambar 3. Distribusi Domisili Pasien Kanker Paru Primer Rumah Sakit Umum Daerah Dr. Soetomo di Jawa Timur Tahun 2017 


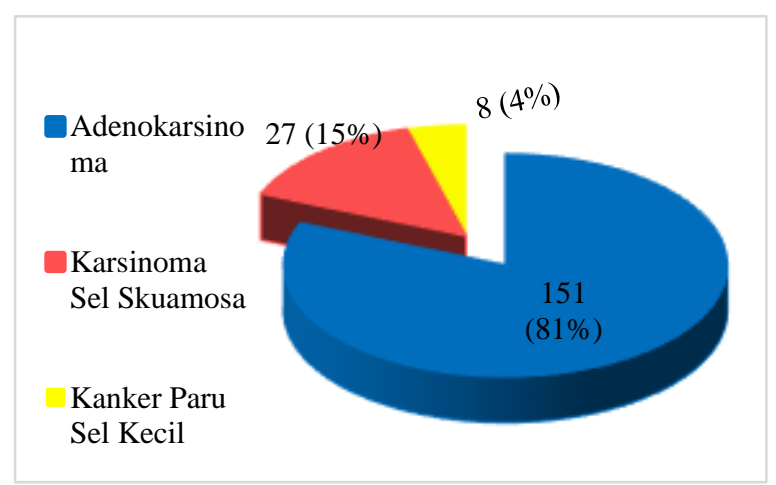

Gambar 5. Distribusi Hitopatologi Anatomi Kanker Paru Primer Pada Pasien Rawat Inap dan Rawat Jalan Rumah Sakit Umum Daerah Dr. Soetomo Tahun 2017

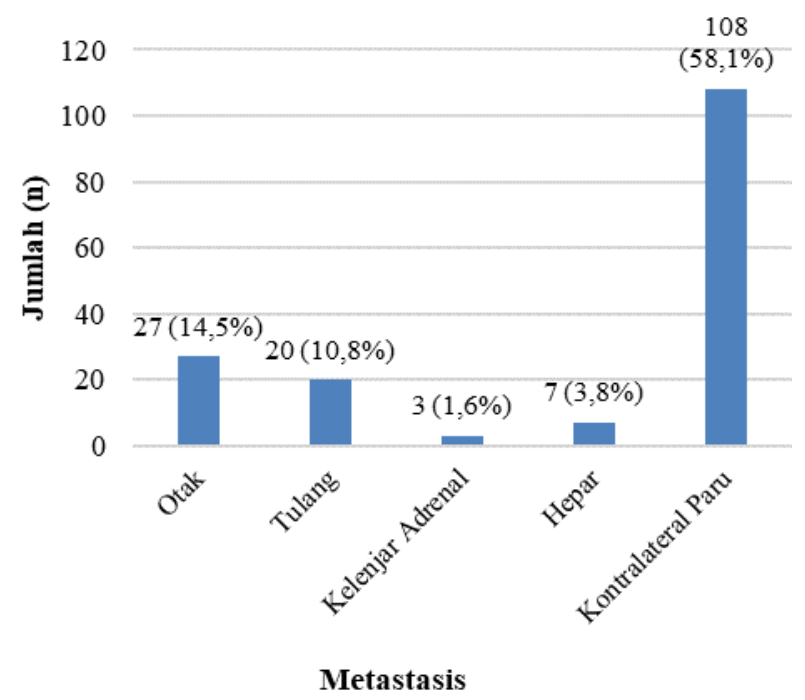

Gambar 6. Distribusi Lokasi Metastasis Kanker Paru Primer Pada Pasien Rawat Inap dan Rawat Jalan Rumah Sakit Umum Daerah Dr. Soetomo Tahun 2017

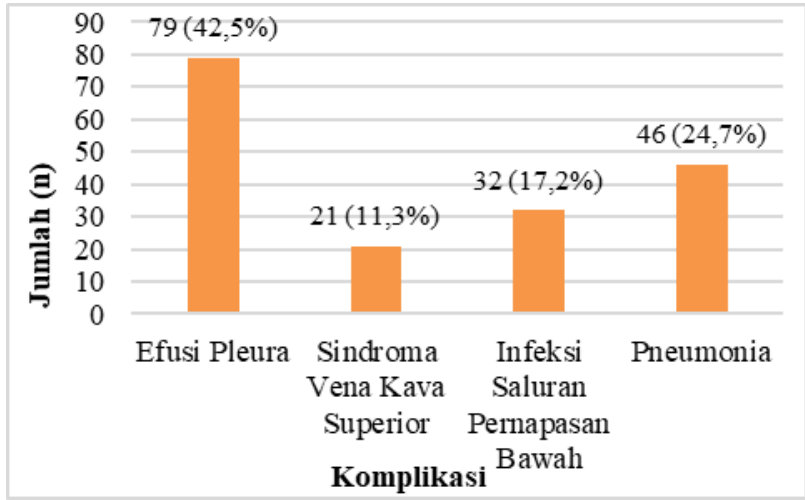

Gambar 7. Distribusi Komplikasi Penyakit Kanker Paru Primer Pada Pasien Rawat Inap dan Rawat Jalan Rumah Sakit Umum Daerah Dr. Soetomo Tahun 2017

Berdasarkan gambar 5 didapatkan bahwa distribusi jenis histopatologi anatomi pasien kanker paru primer terbanyak adalah pada tipe kanker paru bukan sel kecildengan 178 kasus $(95,9 \%)$ dan jarang ditemui pada tipe kanker paru sel kecil dengan 8 kasus $(4,1 \%)$. Adapun subtipe kanker paru primer terbanyak yaitu adenokarsinoma dengan 151 kasus (81\%).

Gambar 6 menunjukkan bahwa pada pasien kanker paru primer stadium IV, lokasi metastasis lokal terbanyak di kontralateral paru $(58,1 \%)$. Adapun lokasi metastasis jauh sering ditemukan pada otak dengan 27 kasus $(14,5 \%)$.

Berdasarkan gambar 7, didapatkan bahwa komplikasi tersering pada pasien kanker paru primer adalah efusi pleura dengan 79 kasus $(42,5 \%)$ diikuti dengan pneumonia dengan 46 kasus $(24,7 \%)$.

Tabel 5. Distribusi Silang Antara Histopatologi Anatomi dengan Lokasi Metastasis Kanker Paru Primer Pada Pasien Rawat Inap dan Rawat Jalan Rumah Sakit Umum Daerah Dr. Soetomo Tahun 2017

\begin{tabular}{|c|c|c|c|c|c|c|c|c|c|c|}
\hline \multirow{3}{*}{ Jenis Histopatologi Anatomi } & \multicolumn{10}{|c|}{ Metastasis } \\
\hline & \multicolumn{2}{|c|}{ Otak } & \multicolumn{2}{|c|}{ Kelenjar Adrenal } & \multicolumn{2}{|c|}{ Tulang } & \multicolumn{2}{|c|}{ Hepar } & \multicolumn{2}{|c|}{ Kontralateral } \\
\hline & $\mathrm{n}$ & $\%$ & $\mathrm{n}$ & $\%$ & $\mathrm{n}$ & $\%$ & $\mathrm{n}$ & $\%$ & $\mathrm{n}$ & $\%$ \\
\hline Adenokarsinoma & 18 & 66,7 & 2 & 66,7 & 16 & 80,0 & 5 & 71,4 & 90 & 83,3 \\
\hline Karsinoma Sel Skuamosa & 8 & 29,6 & 0 & 0,0 & 3 & 15,0 & 0 & 0,0 & 15 & 13,9 \\
\hline Kanker Paru Sel Kecil & 1 & 3,7 & 1 & 33,3 & 1 & 5,0 & 2 & 28,6 & 3 & 2,8 \\
\hline Total & 27 & 100,0 & 3 & 100,0 & 20 & 100,0 & 7 & 100,0 & 108 & 100,0 \\
\hline
\end{tabular}


Tabel 6. Distribusi Terapi Kanker Paru Primer yang Dilakukan di Rumah Sakit Umum Daerah Dr. Soetomo Tahun 2017

\begin{tabular}{lll}
\hline \multirow{2}{*}{ Terapi } & \multicolumn{2}{c}{ Jumlah } \\
\cline { 2 - 3 } & $\mathrm{n}$ & $\%$ \\
\hline Pembedahan & 4 & 2,2 \\
Kemoterapi & 118 & 63,4 \\
Targeted Therapy & 20 & 10,8 \\
Kemoradioterapi & 14 & 7,5 \\
Belum diterapi & 46 & 24,7 \\
\hline
\end{tabular}

Berdasarkan tabel 6, didapatkan terapi yang paling banyak digunakan adalah kemoterapi dengan 118 kasus $(63,4 \%)$, diikuti targeted therapy dengan 20 kasus $(10,8 \%)$, radioterapi dengan 14 kasus $(7,5 \%)$, dan pembedahan dengan 4 kasus $(2,2 \%)$. Namun, ditemukan sebanyak 46 kasus $(24,7 \%)$ belum dilakukan terapi.

Tabel 7. Distribusi Regimen Kemoterapi Kanker Paru Primer yang Dipakai Pada Pasien Rawat Inap dan Rawat Jalan Rumah Sakit Umum Daerah Dr. Soetomo Tahun 2017

\begin{tabular}{|c|c|c|}
\hline \multirow{2}{*}{ Obat Kemoterapi } & \multicolumn{2}{|c|}{ Jumlah } \\
\hline & $\mathbf{N}$ & $\%$ \\
\hline Pemetrexed-Cisplatin & 24 & 17,1 \\
\hline Paclitaxel-Carboplatin & 23 & 16,4 \\
\hline Docetaxel & 21 & 15,0 \\
\hline Gefitinib & 18 & 12,9 \\
\hline Vinorelbin-Cisplatin & 17 & 12,1 \\
\hline Vinorelbin-Carboplatin & 16 & 11,4 \\
\hline Gemcitabin-Carboplatin & 10 & 7,2 \\
\hline Pemetrexed-Carboplatin & 3 & 2,2 \\
\hline Etoposide-Carboplatin & 3 & 2,2 \\
\hline Erlotinib & 2 & 1,4 \\
\hline Docetaxel-Carboplatin & 1 & 0,7 \\
\hline Etoposide-Cisplatin & 1 & 0,7 \\
\hline Platinum based & 1 & 0,7 \\
\hline \multicolumn{3}{|l|}{ (Carboplatin atau Cisplatin) } \\
\hline Total & 140 & 100 \\
\hline
\end{tabular}

Berdasarkan tabel 7, didapatkan obat kemoterapi terbanyak adalah pemetrexed-cisplatin dengan 24 kasus $(17,1 \%)$, paclitaxel-carboplatin dengan 23 kasus (16,4\%), dan docetaxel dengan 21 kasus (15,0\%). Sedangkan pada targeted therapy paling sering digunakan gefitinib dengan 18 kasus $(12,9 \%)$.

\section{PEMBAHASAN}

Pada penelitian ini didapatkan kelompok usia terbanyak pada pasien kanker paru primer yaitu 51-60 tahun $(35,5 \%)$ dengan rata-rata usianya yaitu 55,5 tahun dengan kasus termuda ditemukan pada usia 14 tahun sedangkan tertua pada usia 82 tahun. Hasil ini serupa dengan penelitian di Malabar Cancer Center India dengan kelompok usia terbanyak yaitu 51-60 tahun dengan 112 kasus $(39,9 \%)$ dan variasi hasil ditemukan di RSUP H. Adam Malik Medan dengan kelompok usia terbanyak yaitu 61-70 tahun dengan 28 kasus $(34,6 \%)^{6,7}$ Kelompok usia pasien kanker paru primer antar daerah menurut American Lung Association dapat bervariasi dikarenakan oleh berbagai faktor seperti genetik yang berbeda kerentanannya terhadap polusi kendaraan, mekanisme kekebalan tubuh, fungsi regulasi tubuh terhadap bahan karsinogenik, ras, suku, dan pola hidup dari setiap pasien kanker paru primer di berbagai daerah yang pasti berbeda. ${ }^{8}$

Pada penelitian ini diperolah hasil bahwa pasien kanker paru primer didominasi oleh laki-laki (70,4\%) sedangkan perempuan $(29,6 \%)$ dengan perbandingan 2,3:1. Terdapat kesesuaian hasil dengan penelitian lainnya seperti di Rumah Sakit Paru Shanghai Cina dengan jumlah pasien laki-laki (72,2\%). ${ }^{9}$ Sehingga dapat disimpulkan bahwa kanker paru primer lebih sering terjadi pada laki-laki. Kanker paru primer lebih cenderung terjadi pada laki-laki dapat dikarenakan populasi laki-laki yang merokok lebih banyak daripada perempuan, serta kegiatannya yang banyak di luar rumah sehingga lebih rentan terpapar oleh polusi udara, radiasi, asap rokok. ${ }^{10}$

Latar belakang pendidikan pasien kanker paru primer terbanyak adalah SLTA (70,4\%). Sedangkan latar pendidikan yang jarang ditemui yaitu sarjana $(2,7 \%)$ dan diploma $(1,6 \%)$. Terdapat perbedaan hasil penelitian di daerah lain seperti di Rumah Sakit H. Adam Malik Medan yang mendapati SD dan SLTP $(41 \%)$ menjadi latar belakang pendidikan terbanyak dari pasien kanker paru primer. ${ }^{11}$ Kedua hal ini sejalan dengan penelitian klose yang mengatakan bahwa pendidikan mengenai bahaya merokok sedini mungkin di sekolah dapat menjadi faktor penurun risiko kanker paru primer di masa yang akan datang. ${ }^{12}$ Benazir pada tahun 2013 mengatakan bahwa latar belakang pendidikan yang rendah seperti sekolah dasar dan dibawahnya memiliki hubungan bermakna untuk terkena kanker paru 0,23 lebih besar dibandingkan dengan yang berlatar pendidikan tingkat lanjut. ${ }^{13}$

Pada penelitian ini diapatkan pasien kanker paru primer terbanyak bekerja sebagai pegawai swasta $(38,2 \%)$, dan sedikit ditemukan pada pekerja lepas dan pedagang $(0,5 \%)$, tukang batu, supir, dan pelajar dengan masing-masing $1,1 \%$. Pekerjaan merupakan salah satu faktor risiko kanker paru primer. Paparan polusi di dalam dan luar ruangan kerja (indoor dan outdoor) seperti penggunaan bahan bakar padat rumahan (kayu, arang, dan lainnya) untuk masak dan kebutuhan lainnya seringkali diikuti ventilasi yang buruk dan rentan terkena paparan karsinogenik seperti arsen, asbes, silika dan lainnya. ${ }^{14,15} \mathrm{Hal}$ ini meningkatkan frekuensi paparan karsinogenik dari gas buangan bakar tersebut seperti benzoapirene, formaldehide, dan benzene sehingga risiko kanker paru meningkat khususnya pada populasi yang tidak merokok. ${ }^{16}$ 
Kota Surabaya dan Sidoarjo memiliki karekteristik yang sama yaitu mobilitas kerja yang tinggi. Hal ini menyebabkan polusi udara di daerah tersebut juga lebih tinggi dibanding daerah lain. Penelitian Samet dkk menyebutkan bahwa angka polusi udara yang tinggi memiliki hubungan dalam meningkatnya risiko kasus kanker paru primer. ${ }^{17}$

Gejala klinis yang paling sering dialami pasien kanker paru primer adalah sesak napas $(59,1 \%)$. Gejala klinis yang timbul merupakan manifestasi dari perkembangan kanker paru primer yang dapat menginvasi daerah sekitarnya sehingga dapat bervariasi antara pasien satu dengan yang lainnya. ${ }^{18}$

Histopatologi anatomi terbanyak pada pasien kanker paru primer adalah tipe kanker paru bukan sel kecil yaitu adenokarsinoma baik pada laki-laki dengan 103 kasus $(78,6 \%)$ dan perempuan dengan 48 kasus (87,3\%). Kanker paru primer dengan jenis histopatologi anatomi adenokarsinoma merupakan jenis yang paling banyak ditemui. Pada sebuah penelitian dijelaskan bahwa merokok menggunakan filter dengan nikotin yang sedikit membuat hirupan asap rokok menjadi lebih dalam untuk mendapatkan sensasi senang sehingga berefek pada daerah perifer paru yang merupakan tempat tersering ditemukan adenokarsinoma. ${ }^{19}$

Stadium kanker paru primer menunjukkan sejauh mana kanker telah berkembang. Semakin tinggi stadium yang diketahui saat pasien terdiagnosis kanker paru primer, maka prognosis akan semakin buruk. Sebuah penelitian di India mendapati bahwa mayoritas kanker paru primer terdiagnosa pada stadium lanjut yaitu stadium III dan IV. ${ }^{6}$ Hasil penelitian ini sesuai dengan penelitian di atas dengan stadium terbanyak yaitu stadium IV $(80,1 \%)$ diikuti stadium III (14\%). Melihat hasil demikian, dapat disimpulkan bahwa kasus kanker paru primer rata-rata terdiagnosa pada stadium lanjut (III dan IV).

Pada penelitian ini didapatkan hasil metastasis terbanyak pada pasien kanker paru primer adalah pada kontralateral paru yaitu sebesar 58,1\%. Kontralateral adalah keadaan berkebalikan, dimana apabila pasien menderita kanker di paru kiri maka kanker sudah bermetastasis di paru kanan, begitu sebaliknya. Proses metastase pada kanker biasanya menyerang bagian tubuh kontralateral dahulu baru kemudian menyebar ke organ lain. ${ }^{20}$ Metastasis kontralateral paru umumnya terjadi pada adenokarsinoma dan skuamous sel skuamosa melalui mekanisme connexin-43 yang memfasilitasi sel kanker menempel pada endotel paru. ${ }^{21}$

Pada penelitian ini didapatkan hasil yaitu efusi pleura menjadi komplikasi kanker paru primer tersering $(42,5 \%)$ diikuti dengan pneumonia $(24,7 \%)$. Kanker paru primer dapat menimbulkan banyak komplikasi.
Efusi pleura terjadi sebagai akibat dari invasi sel kanker yang mengarah langsung ke daerah tersebut. Pneumonia terjadi akibat dari efek kemoterapi yang memicu akumulasi sel sitotoksik dan lebih lanjut dapat menjadi infeksi saluran pernapasan. ${ }^{22}$

Pada penelitian ini didapatkan hasil bahwa kemoterapi menjadi terapi yang paling banyak digunakan pada pasien kanker paru primer $(63,4 \%)$. Hal ini dikarenakan mayoritas pasien kanker paru primer RSUD Dr. Soetomo berada pada stadium IV sehingga menurut Panduan Penatalaksanaan Kanker Paru (PPKP) pada stadium lanjut disarankan dengan memberi terapi yang bersifat multimodalitas seperti kemoterapi dan radioterapi. $^{23}$

Pada penelitian ini, dari 186 pasien yang terdiagnosa kanker paru primer, yang mendapatkan kemoterapi adalah 140 pasien. Adapun obat kemoterapi terbanyak adalah 2 kombinasi obat yaitu pemetrexedcisplatin dengan $(17,1 \%)$. Hasil ini sesuai dengan sebuah jurnal yang mengatakan bahwa kemoterapi kombinasi 2 obat dengan salah satu obatnya adalah platinum-based (carboplatin, siplatin, dan oxaliplatin) dipakai sebagai standar terapi pada kanker paru primer stadium lanjut. ${ }^{24}$

\section{KESIMPULAN}

Pasien kanker paru primer Rumah Sakit Umum Daerah Dr. Soetomo yang dirawat inap dan rawat jalan dominan pada rentang usia 51-60 tahun. Metastasis lokal terbanyak ditemukan di kontralateral paru dan metastasis jauh sering ditemukan di otak. Komplikasi terbanyak yaitu efusi pleura. Perlu adanya deteksi dini dengan memperhatikan karakteristik kanker paru di setiap daerah dan manajemen komplikasi penyakit kanker paru primer dapat diantisipasi dengan baik agar tingkat kelangsungan hidup pasien dapat meningkat.

\section{DAFTAR PUSTAKA}

1. Kementerian kesehatan Republik Indonesia. Panduan Penatalaksanaan Kanker Paru [Internet]. 2017. p. 6-13. Available from: http://kanker.kemkes.go.id/ guidelines/PNPKParu.pdf

2. World Health Organization. WHO Cancer Fact Sheet [Internet]. 2018 [cited 2018 Apr 10]. Available from: https://www.who.int/news-room/fact-sheets/detail/cancer

3. American Cancer Society. Key Statistics for Lung Cancer [Internet]. 2018 [cited 2018 Apr 10]. Available from: https://www.cancer.org/cancer/lung-cancer/about/keystatistics.html

4. World Health Organization. WHO Cancer Country Profiles [Internet]. 2014. Available from: https:// www.who.int/cancer/country-profiles/en/

5. National Cancer Institute. SEER Lung Cancer statistic Review 1975-2015 [Internet]. 2015 [cited 2018 Apr 15]. Available from: https://seer.cancer. gov/archive/csr/1975_2015/ 
6. Bhaskarapillai B, Kumar SS, Balasubramanian S. Lung cancer in malabar cancer center in kerala - A descriptive analysis. Asian Pacific J Cancer Prev. 2012;13(9):463943.

7. Tumanggor MG. Karakteristik Penderita Kanker Paru Primer Di Departemen Ilmu Penyakit Paru RSUP Haji Adam Malik Medan Periode Januari 2011 -Desember 2012. Repos USU. 2013;8-11.

8. American Lung Association. State of Lung Disease in Diverse Communities 2010 [Internet]. Lung USA. 2010. Available from: http://action.lung.org/ site/DocServer/state-of-lung-disease-in-diversecommunities-2010.pdf?docID=8744

9. Shan S, She J, Xue ZQ, Su CX, Ren SX, Wu FY. Clinical characteristics and survival of lung cancer patients associated with multiple primary malignancies. PLoS One. 2017;12(9):e0185485.

10. Alberg AJ, Wallace K, Silvestri GA, Brock M V. Invited commentary: The etiology of lung cancer in men compared with women. Am J Epidemiol. 2013;177(7):613-6.

11. BR.G M. Karakteristik Penderita Kanker Paru Rawat Inap Di RSUP H. Adam Malik Medan Tahun 2004-2008. 2010.

12. Klose C. A Descriptive Analysis of Lung Cancer in Montgomery County, Ohio. Master Public Heal Progr. 2012;19-28.

13. Benazir S, Yovsyah. Faktor Risiko Kejadian Kanker Paru pada Pasien Rawat Inap dan Rawat dan Rawat Jalan di RSUPN Dr. Cipto Mangunkusumo Jakarta Tahun 2011-2012. FKM UI. 2013;5-7.

14. Rehfuess E, Mehta S, Prüss-Üstün A. Assessing household solid fuel use: Multiple implications for the Millennium Development Goals. Environ Health Perspect. 2006;114(3):373-8.

15. Siemiatycki J, Richardson L, Straif K, Latreille B, Lakhani R, Campbell S, et al. Listing occupational carcinogens. Environ Health Perspect. 2004;112:144759.
16. Lissowska J, Bardin-Mikolajczak A, Fletcher T, Zaridze D, Szeszenia-Dabrowska N, Rudnai P, et al. Lung cancer and indoor pollution from heating and cooking with solid fuels: The IARC international multicentre case-control study in Eastern/Central Europe and the United Kingdom. Am J Epidemiol. 2005;162(4):326-33.

17. Samet JM, Avila-Tang E, Boffetta P, Hannan LM, Olivo-Marston S, Thun MJ, et al. Lung cancer in never smokers: Clinical epidemiology and environmental risk factors. Clin Cancer Res. 2009;67(4):5626-45.

18. PATEL AM, PETERS SG. Clinical Manifestations of Lung Cancer. Mayo Clin Proc. 1993;68(3):273-7.

19. Devesa SS, Bray F, Vizcaino AP, Parkin DM. International lung cancer trends by histologic type: Male:female differences diminishing and adenocarcinoma rates rising. Int $\mathbf{J}$ Cancer. 2005;117(2):294-9.

20. Febriani A, Furqon A, Metastasis Kanker Paru. Jurnal Respirasi 2018; 4(3): 94-101. http://dx.doi.org/10.20473/jr.v4-I.3.2018.94-101

21. Elzarrad MK, Haroon A, Willecke K, Dobrowolski R, Gillespie MN, Al-Mehdi AB. Connexin-43 upregulation in micrometastases and tumor vasculature and its role in tumor cell attachment to pulmonary endothelium. BMC Med. 2008;6(20):1-14.

22. Abdel Rahman, Ahmed;El-Helbawy R;Youssef, M;Megid Algizy, H;Abu-Shady M. Assessment of neutrophil/lymphocyte percentage in bronchial asthma. Eqyptian J Chest Dis Tuberc. 2019;68(1):74-9.

23. Kementerian Kesehatan Republik Indonesia. Pedoman Nasional Pelayanan Kedokteran : Kanker Paru [Internet]. 2017. p. 7. Available from: http://kanker.kemkes.go.id/guidelines/PNPKParu.pdf

24. Molina JR, Yang P, Cassivi SD, Schild SE, Adjei AA. Non-small cell lung cancer: Epidemiology, risk factors, treatment, and survivorship. In: Mayo Clinic Proceedings. 2008. p. 584-94. 